\title{
Expert System Identification Of Learning Patterns The VARK Method With Certainy Factor
}

\author{
Linda Marlinda \\ STMIK Nusa Mandiri \\ Jakarta, Indonesia \\ linda.ldm@nusamandiri.ac.id
}

\author{
Dwiki Saputra \\ STMIK Nusa Mandiri \\ Jakarta, Indonesia \\ dwikisyahputra90@yahoo.co.id
}

\author{
Wahyu Indrarti \\ Universitas Bina Sarana Informatika \\ Jakarta, Indonesia \\ wahyu.wii@bsi.ac.id
}

\begin{abstract}
Nowadays computers have been widely used by many people, both parents, children, and adolescents. Basically, they only follow technological progress. And it eventually led to progress in the field of science. On the other hand, the background of the need for the seriousness of parents in knowing the pattern of their children's learning style is the amount of potential free time that is not well utilized by children in the learning process. Plus the number of parents who do not support children in developing their own mindset. Or the learning atmosphere that is still not conducive. In line with the advancement of technology and science, parents should be able to easily find out the right pattern of children's learning styles, to make it easier for their children to develop their mindset and imagination in the world of learning. And one of them can be by using an expert system. The expert system for identifying patterns of children's learning styles is an expert system designed as a tool for parents to identify patterns of children's learning styles with a dynamic knowledge base. This knowledge is obtained from various sources, including research carried out by experts in their fields and books related to learning styles. The knowledge base is arranged in such a way into logic with several provisions including the vark method (visual, auditory, read/write, kinesthetic), in order to facilitate system performance in making conclusions. Drawing conclusions in this expert system use the certainty factor method. This expert system will display several questions as indicators of the characteristics of the child's learning style that are felt, then later arrive at the final question. The conclusion of this study using the certainty factor method will be to show the characteristics of the children's learning styles. With the obtained from the visual learning style (0.144) with symptoms of MB (0.2) and MD $(0.1)$; auditory learning style $(0.28)$ with symptoms of watch videos and movies at $\mathrm{MB}$ (0.6) and MD $(0,1)$; read / write learning style $(0.31)$ with symptoms, material read study and summarize the material MB $(0.2)$ and $\mathrm{MD}(0,1)$; and kinesthetic learning style $(0.38)$ with can move symptoms, the body (a) is positive (MB) (0.8) and MD (0.3).
\end{abstract}

Keywords - Expert System, Learning Style, VARK Method, Certainty Factor 


\section{INTRODUCTION}

The world of education is a region that is very much considered by parents because in the world a child's education can be formed, both its character, behavior, mindset and even learning patterns (Makrufi n.d.). Even the government is very concerned about the world of the nation's future education, one of which is the 12-year compulsory education program, even though it has received excellent support from the government, sometimes there are children who deliberately waste available free time, so that free time what is available which should be a time to deepen knowledge becomes futile (Muh et al. 2017).

A combination of learning absorbed by students and then processing it into information and developing new information is called learning style. One of the tasks of parents in educating children is to provide support both morally and materially, but the fact now is that there are some parents who lack support for their children in developing their own mindset(Kadarwati n.d.).

If the atmosphere of the house is good, the atmosphere of the school is also good, and the environment is good, then the children's learning style will also indirectly be good, because one of the most dominant factors in influencing the pattern of children's learning is environmental factors (Harris, Administrasi, and Fkip n.d.), therefore parents should be guides for children in building a conducive and interactive learning environment for their children, especially when children are inside the house (Belajar 1990).

Generally, there is some intelligence that can describe a person who is in intelligence, so that they can provide direction in developing talents as well as knowing the patterns of learning styles, and basically every human being has a tendency to their respective intelligence, from these tendencies, arises several methods in knowing a child is in what intelligence(Penegakan et al. 2014).

\section{LiterATURE REVIEW}

\section{A. Expert System}

A good expert system is designed to be able to solve a particular problem by imitating the work of experts (Informasi et al. 2016). With this expert system, even lay people can solve complex problems, which can only be solved with the help of experts. For experts, this expert system will also help its activities as a highly experienced assistant(Prasetyo and Iqbal 2016)
Expert System is one of the branches of Artificial Intelligence that makes extensive use of knowledge specifically for expert human-level problemsolving(Tasikmalaya et al. 2012). An expert is a person who has expertise in a particular field, namely an expert who has special knowledge or abilities that other people do not know or are capable of in their fields(Marlinda 2015).

The expert system component consists of 5 components, namely(Tasikmalaya et al. 2012):

1. Knowledge Base

a. The core expert system program;

b. Is a representation of knowledge from an expert;

c. Composed of facts in the form of provisions/rules and objects which are information about how to generate new facts from known facts.

2. Inference Engine

a. Parts that contain mechanisms for the functions of thinking and systems of reasoning patterns used by an expert;

b. This mechanism will analyze a particular problem and then look for the best answer or conclusion;

c. Selecting relevant knowledge in order to reach a certain conclusion;

d. Start tracking it by matching the rules in the knowledge base with the facts, in the list of facts (fact list) that are stored in the knowledge base on the hard disk.

3. User Interface(Ibrohim et al. 2017)

a. The connecting part between the expert system and the user;

b. There will be a dialogue between the program and the user;

c. The program will ask questions in the form of menu guides, natural language statements, and graphics interface styles. Expert system program created will draw conclusions based on the answers of the user.

4. Development Engine

Part of the expert system that functions as a facility to develop inference engines and the addition of a knowledge base that the knowledge engineer will do or must have expertise in understanding how experts apply their knowledge in solving a problem, and also able to extract knowledge acquisition of expert knowledge, if the expert finds new knowledge and rules from his experience of working.

5. Interface technique There are two techniques for doing an interface: 
a. Backward chaining which starts the reasoning from the conclusion (goal), by searching for a set of supporting hypotheses towards the facts that support a set of hypotheses;

b. Forward chaining starts from a set of facts by looking for a rule that fits the guess/hypothesis that leads to conclusions.

\section{B. Symptoms}

A person's ability to understand and absorb lessons that are certainly different levels. Some are very slow, medium, and some are fast. Therefore, they often take different ways to understand the same information or lessons. Learning style is a unique way of learning for students(Muh et al. 2017)

Regarding one's learning style, researchers agree in general there are two main categories. First, how to absorb information and how to organize and process information. This interpretation gave birth to a formulation of learning modalities abbreviated as VARK(Tasikmalaya et al. 2012) (i.e., Visual, Auditor, and Kinesthetic modalities)

Types of visual modalities, students absorb knowledge through what they see. Auditory types, students absorb knowledge through what they hear. Finally the kinesthetic type, students absorb knowledge through motion and touch. So, varied learning methods strongly support the acceleration of the achievement of learning objectives that have been formulated(Ibrohim et al. 2017).

A person's ability to understand and absorb lessons that are certainly different levels. Some are very slow, medium, and some are fast. Therefore, they often take different ways to understand the same information or lessons. Learning style is a unique way of learning for students(Muh et al. 2017).

\section{VARK Method}

The model of learning style must be understood by every teacher of each student because it is very influential in the teaching and learning process in the classroom. Which must be understood by students and cannot be identified by the teacher, because the questions are different types of questions so special attention and discipline are needed to determine the abilities of students.

The VARK learning style is the most and easy to use. Among them(Tasikmalaya et al. 2012):

a. visual learning style is Visual learning is very regular learning of ideas and concepts that are visually depicted with quiet and detailed. A distinctive feature of visual learning has learning patterns that can be remembered like colors and space. Students can easily remember what is seen as interestingly.

b. Auditory (Learning with Hearing), Listen, and listen, the teacher answers the question in the middle of the video playback. To stimulate students, there will be a desire to express opinions, ideas, respond and debate. Students prefer to listen to audio tapes, lectures, discussions, debates and verbal instructions (orders). Note tool is very helpful for auditor type student learning.(Gani and Nasution n.d.)

c. Kinesthetic (Learning with Movement, Working, and Touching)

d. Learning through physical activity and direct involvement. Students are asked to do a written test of the questions posed by the teacher. So that the teacher is able to deduce the desired indicator. Students not only see and hear but move, and speak in front.(Laksana 2017)

VARK Learning Method (Kinesthetic Visual Auditory)(Laksana 2017) uses three main senses of the recipient, namely Visual Auditory Kinesthetic originating from a world that is fast and popular because of its simplicity. According to the VARK theory, the need to present information uses all three styles. This allows all students to have the opportunity to be involved, no matter what style they choose. This learning model assumes that learning will be effective by paying attention to the three things mentioned above, namely Visualization, Auditory and Kinesthetic in other words to use the potential of the students they already have by training, developing it(Ersa and Dewi 2018).

\section{Certainty Factor}

The designated value as a measure of certainty for a rule fact and the amount of trust is called a certainty factor consisting of two stages of the model of the rule used:

1. Using the calculation method The certainty factor shows a measure of certainty of a factor rule. Certainty factor notation Certainty factor provides the concept of measure of belief (MB) and the measure of disbelief (MD).

2. The results of interviews with experts can judge $\mathrm{CF}$ to be the MD value or MB of a rule by several methods.

Certainty theory uses a value called certainty factor (CF) to assume the degree of confidence an expert has in data in expressing degrees of belief. This concept is then formulated in the $\mathrm{CF}$ equation 


$$
(\mathrm{H}, \mathrm{E})=\mathrm{MB}(\mathrm{H}, \mathrm{E})-(\mathrm{MD}(\mathrm{H}, \mathrm{E})
$$

a. $\mathrm{CF}(\mathrm{H}, \mathrm{E})$ : $\mathrm{CF}$ of hypothesis $\mathrm{H}$ is affected by symptoms of E.

b. The magnitude of CF (-1 (indicates unbelief) up to 1 (absolute trust)

c. $\mathrm{MB}(\mathrm{H}, \mathrm{E})$ the size of the increase in hypothesis H's confidence is affected by the symptoms of $\mathrm{E}$.

d. $\mathrm{MD}(\mathrm{H}, \mathrm{E})$ measures the increase in hypothesis $\mathrm{H}$ distrust that is affected by $\mathrm{E}$ symptoms

$\mathrm{CF}$ parallel is the final $\mathrm{CF}$ of a candidate conclusion. Parallel CF is needed if a conclusion is obtained from several rules at once. CF The end of a rule with other rules combined to get the final $\mathrm{CF}$ value for the candidate conclusion. Parallel CFs are represented in the following equations

$\mathrm{CF}(\mathrm{H} \mid \mathrm{E} 1 ; \mathrm{E} 2)=\mathrm{CF}[\mathrm{MB}(\mathrm{H} \mid \mathrm{E} 1)]+\mathrm{CF}[\mathrm{MB}$ $(\mathrm{H} \mid \mathrm{E} 2)] \times[1-[\mathrm{MB}(\mathrm{H} \mid \mathrm{E} 1)]]$

Where :

a. $\quad \mathrm{CF}(\mathrm{H} \mid \mathrm{E} 1 ; \mathrm{E} 2)=$ Parallel Certainty Factor in hypothesis $\mathrm{H}$ which is affected by symptoms $\mathrm{E} 1$ and $\mathrm{E} 2$

b. $\mathrm{CF}[\mathrm{MB}(\mathrm{H} \mid \mathrm{E} 2)]=$ Measure of Belief is a measure of the increase in trust in hypothesis $\mathrm{H}$ affected by symptoms E1 (between 0 and 1)

c. $[1-[\mathrm{MB}(\mathrm{H} \mid \mathrm{E} 1)]]=$ Measure of Belief is a measure of the increase in trust in hypothesis $\mathrm{H}$ affected by symptoms of E2.

\section{Proposed Method}

Sampling / Sample Selection Method

This study uses knowledge or symptom codes (B1 ... B20), with learning style choices (A1..A4) with data and information collected from student respondents and teachers learning at schools randomly using interview techniques, observation or observation and filling in direct and literature study by looking for literature on student learning styles.

\section{Method of collecting data}

The research begins with analyzing needs and making models in the form of questionnaires and given to several respondents. Basic data that has been obtained is used in consulting operations and as material to be represented using production rules, by entering definite truth values into the input in the form of questions and perceived symptoms by making rules or rules used in certainty factor.

\section{RESULT AND DISCUSSION}

This knowledge base can identify learning patterns using VARK which contains a choice of methods that will be applied by the teacher to students in order to obtain a maximum teaching system. Types of Learning Styles (Conclusions)

Table 1. Code of Learning Style Types

\begin{tabular}{|c|l|}
\hline Code & \multicolumn{1}{|c|}{ Types of Learning Styles } \\
\hline A1 & Visual \\
\hline A2 & Auditor \\
\hline A3 & Read/Write \\
\hline A4 & Kinestetik \\
\hline
\end{tabular}

Table II. Characteristics (Symptoms)

\begin{tabular}{|c|c|c|c|}
\hline Code & Characteristic features & MD & MB \\
\hline B1 & $\begin{array}{l}\text { Attractive viewing colored } \\
\text { images Easily see and draw } \\
\text { graphics }\end{array}$ & 0,2 & 0,1 \\
\hline B2 & $\begin{array}{l}\text { Showing pictures of } \\
\text { vacation spots }\end{array}$ & 0,3 & 0,1 \\
\hline B3 & $\begin{array}{l}\text { See moving images on the } \\
\text { internet online }\end{array}$ & 0,4 & 0,2 \\
\hline B4 & $\begin{array}{l}\text { Easily understand moving } \\
\text { images in full color }\end{array}$ & 0,5 & 0,3 \\
\hline B5 & $\begin{array}{l}\text { It's easier to hear loud and } \\
\text { clear sounds }\end{array}$ & 0,6 & 0,4 \\
\hline B6 & $\begin{array}{l}\text { Listen to cheerful music } \\
\text { with moving images }\end{array}$ & 0,4 & 0,2 \\
\hline B7 & $\begin{array}{l}\text { Ease to see mouth } \\
\text { movements }\end{array}$ & 0,3 & 0,2 \\
\hline B8 & $\begin{array}{l}\text { Ask him about what he } \\
\text { heard }\end{array}$ & 0,2 & 0,1 \\
\hline B9 & $\begin{array}{l}\text { Read the writings with } \\
\text { sound so that it is easier to } \\
\text { remember }\end{array}$ & 0,6 & 0,3 \\
\hline B10 & Write directions & 0,2 & 0,1 \\
\hline B11 & Read writing and numbers & 0,6 & 0,2 \\
\hline B12 & $\begin{array}{llr}\begin{array}{l}\text { Looking } \\
\text { information } \\
\text { website }\end{array} & \begin{array}{l}\text { for } \\
\text { through }\end{array} & \text { thews } \\
\end{array}$ & 0,7 & 0,4 \\
\hline B13 & $\begin{array}{l}\text { Imitate the guidebook given } \\
\text { by experts }\end{array}$ & 0,3 & 0,1 \\
\hline B14 & $\begin{array}{l}\text { Read study material and } \\
\text { summarize the material }\end{array}$ & 0,5 & 0,2 \\
\hline
\end{tabular}




\begin{tabular}{|c|c|c|c|}
\hline B15 & $\begin{array}{l}\text { Deliver it to the destination } \\
\text { address }\end{array}$ & 0,8 & 0,4 \\
\hline B16 & Watch videos and movies & 0,4 & 0,2 \\
\hline B17 & $\begin{array}{l}\text { Can explain sentence points } \\
\text { in the outline }\end{array}$ & 0,4 & 0,2 \\
\hline B18 & Can make sentences well & 0,4 & 0,2 \\
\hline B19 & $\begin{array}{l}\text { Read and hear and translate } \\
\text { in the form of sentences and } \\
\text { images }\end{array}$ & 0,3 & 0,2 \\
\hline B20 & $\begin{array}{l}\text { Can move the body with a } \\
\text { positive response from what } \\
\text { is seen and heard }\end{array}$ & 0,2 & 0,1 \\
\hline
\end{tabular}

An expert tree is an inference engine made based on the results of processing from the Certainty Factor method. From the table above the table can be illustrated by the expert tree as follows:

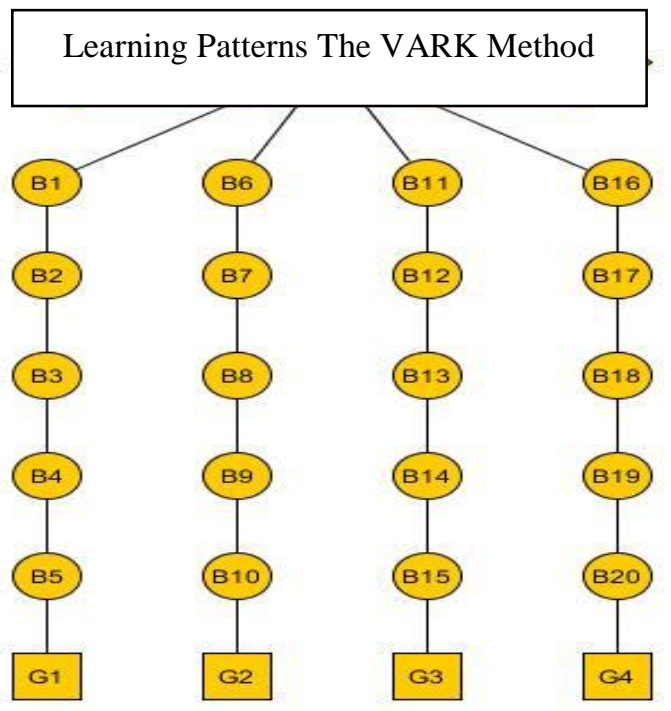

Picture. 1 expert tree

Calculations from the learning style test questionnaire were conducted to determine the percentage comparison of scores between visual, aural, $\mathrm{read} / \mathrm{write}$ and kinesthetic from student answers. Calculations from the learning style test questionnaire use the following formula:

1. Rule 1 or Rule 1

In rule 1 (Rule 1), we can determine the rules used to produce the "Visual" .

IF B1, B2, B3, B4, B5

THEN Results with the title "G1= Visual"
2. Rule 2 or Rule 2

In rule 2 (Rule 2), we can determine the rules used to produce the "Auditor".

IF B6, B7, B8, B9, B10

THEN Results with the title "G2= Auditor"

3. Rule 3 or Rule 3

In rule 3 (Rule 3), we can determine the rules used to produce the "Read/write".

IF B11,B12,B13,B14,B15

THEN Results with the title "Read/write"

4. Rule 4 or Rule 4

In rule 4 (Rule 4), we can determine the rules used to produce the title "Kinesthetic".

IF B16,B17,B18,B19,B20

THEN Results with the title "Kinesthetic"

Based on calculations using the formula, the sequence of percent values of each attribute will be obtained.
Table III. Expert Table 


\begin{tabular}{|c|c|c|c|c|c|}
\hline & 篱 & G1 & G2 & G3 & G4 \\
\hline \multirow{20}{*}{ 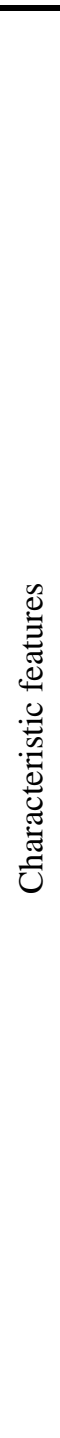 } & B1 & $\checkmark$ & & & \\
\hline & B2 & $\checkmark$ & & & \\
\hline & B3 & $\checkmark$ & & & \\
\hline & B4 & $\checkmark$ & & & \\
\hline & B5 & $\checkmark$ & & & \\
\hline & B6 & & $\checkmark$ & & \\
\hline & B7 & & $\checkmark$ & & \\
\hline & B8 & & $\checkmark$ & & \\
\hline & B9 & & $\checkmark$ & & \\
\hline & B10 & & $\checkmark$ & & \\
\hline & B11 & & & $\checkmark$ & \\
\hline & B12 & & & $\checkmark$ & \\
\hline & B13 & & & $\checkmark$ & \\
\hline & B14 & & & $\checkmark$ & \\
\hline & B15 & & & $\checkmark$ & \\
\hline & B16 & & & & $\checkmark$ \\
\hline & B17 & & & & $\checkmark$ \\
\hline & B18 & & & & $\checkmark$ \\
\hline & B19 & & & & $\checkmark$ \\
\hline & B20 & & & & $\checkmark$ \\
\hline
\end{tabular}

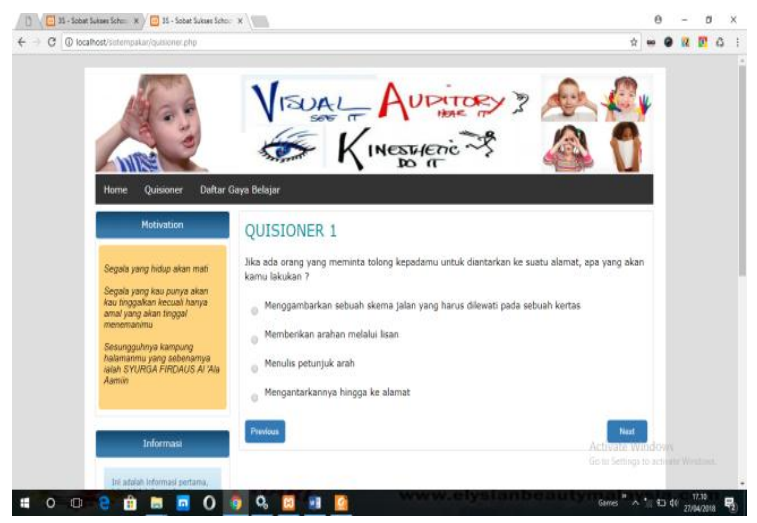

Picture 2. expert system learning style vark method

\section{CONClusion}

Many of the available free time potentials are poorly utilized, and after parents know the learning styles that their children have, then parents can help their children manage their free time to be more useful by doing things other positive things, which can improve the child's learning style again. Many children are not supported in developing their own mindset, and after parents know the learning style that their children have, then it is appropriate for parents to give a trust to their children, so that their children can develop their own mindset, as long as they are still in the room good scope, and if the child's mindset has begun to indicate negatively, then as a parent it is appropriate to be a guide for their child, to return to a good and right mindset. The need to build a conducive and interactive learning atmosphere. Which aims so that children can easily get knowledge well. There are parents who do not know which child is in a learning style, which results in a lack of understanding of parents in helping direct their children, so that parents sometimes focus on one learning style, but in reality children have other learning styles, and after parents know which child is in a learning style which, then as parents will be easier in leading. Sometimes there are children who are easily affected by the environment, not why if they are affected by the good, it is different if it affects the bad direction, then the child will be carried away to the bad direction, and even worse, the child will fall deep into the black hole. But after parents know the learning style of their children, parents are expected to be easier to direct their children to a good environment, and can also strengthen the strong rationale through learning methods that are suitable for children's learning styles, or by giving inputpositive input to the child, and if indeed the child has fallen into a black hole, parents are expected to be easier, give moral encouragement by paying attention to the child's learning style, so that the child can 
receive the input well, and within a certain period of time, allowing children to return to the good path.

\section{REFERENCES}

Belajar, Anak Dalam. 1990. "No Title.” : 1-22.

Ersa, Putu, And Rahayu Dewi. 2018. "Pemanfaatan Multimedia Presentasi Dan Media Cetak Dalam Meningkatkan Mutu." 4: 115-30.

Harris, Taufiq, Prodi Administrasi, And Pendidikan Fkip. "Dan Model Penerimaan Peserta Didik Baru Melalui Reformasi Sekolah." : 9-18.

Ibrohim, Muhamad Et Al. 2017. "Rancang Bangun Aplikasi Identifikasi Gaya Belajar Siswa Dengan Metode Forward Chaining ( Studi Kasus : Sekolah Dasar Negeri Sumampir )." 4(2003): 19-28.

Informasi, Sistem Et Al. 2016. "Sniptek 2016 Sistem Pakar Diagnosa Penyakit Kulit Pada Balita Dengan Seminar Nasional Ilmu Pengetahuan Dan Teknologi Komputer Nusa Mandiri Seminar Nasional Ilmu Pengetahuan Dan Teknologi Komputer Nusa Mandiri.” : 375-82.

Kadarwati, Sri. "Mengembangkan Kecerdasan Anak Usia Dini Melalui Pembelajaran Berbasis Pendidikan Kreatif." 2(1): 43-66.

Laksana, Ngurah Laba. 2017. "Desain Pembelajaran
Kontekstual Spirit Kearifan Lokal Medamazi Untuk Siswa Sekolah Dasar.” 2017 (November): 195-202.

Makrufi, Anisa Dwi. "Model Pendidikan Islam Dengan Pendekatan Multiple Intelligences.” : 153-70.

Marlinda, Linda. 2015. "Menggunakan Apotek Hidup Menggunakan Simple Additive Weighting." (November): 1-5.

Muh, Lalu, Supriadi Wirya, Lanang Agung Parwata, And Kusuma Wijaya. 2017. "Pengaruh Model Pembelajaran Kooperatif Tipe Gi.” 8(2).

Penegakan, Materi, H A M Kelas, X Bina Prestasi, And D I Man. 2014. "No Title."

Prasetyo, Tri Ferga, And Muhammad Iqbal. 2016. "Sistem Pakar Identifikasi Gaya Belajar Mahasiswa Berbasis Web." (November): 1-7.

Tasikmalaya, Kota, Jawa Barat, Karakteristik Gaya Belajar, And Forward Chaining. 2012. "Aplikasi Pakar Untuk Mengidentifikasi Karakteristik Gaya Belajar Dengan Menerapkan Modalitas Vark.” (X). 